\title{
JMLE
}

The National Association for Media Literacy Education's

Journal of Media Literacy Education 11 (1), 114 - 119

https://doi.org/10.23860/JMLE-2019-11-1-6

\section{BOOK REVEW \\ Breakbeat Pedagogy: Hip Hop and Spoken Word Beyond the Classroom Walls}

\author{
Reviewed by \\ Drew Emanuel Berkowitz \\ Montclair State University
}

\begin{abstract}
Mooney, Brian (2016). Breakbeat Pedagogy: Hip Hop and Spoken Word Beyond the Classroom Walls. Foreword by Christopher Emdin. New York: Peter Lang.
\end{abstract}

I'm from standing on line at the library with eight books stacked above my head. Librarians like police officers. Nail polish bullets through her pistol hands 'Put those back, kid. You wouldn't know how to read all those' (p. 58)

- Brian Mooney, quoting “An Ode to Jersey City” by Hadee

On June 8th, 2015, twelve-time Grammy Award-winning Hip Hop artist Kendrick Lamar visited an urban public magnet high school in North Bergen, New Jersey, in order to participate in an afternoon-long discussion of Hip Hop media literacy that would later be characterized by National Public Radio reporter Sami Yenigun as "the best day of school ever" (Yenigun, 2015, p. 1). Lamar was inspired to visit after reading a blog post by North Bergen teacher Brian Mooney, who has employed a range of socio-cultural media literacy pedagogies in order to adapt Hip Hop media practices to his students' in-school literacy learning experiences.

Mooney's book, Breakbeat Pedagogy: Hip Hop and Spoken Word Beyond the Classroom Walls, contains a mixture of case study findings and autoethnographic observations, providing insight on not only Mooney's approach to 
critical media literacy pedagogy, but also his views on the role straight, white, cisgender male educators play in the media literacy education of increasinglydiverse high school student bodies.

Breakbeat Pedagogy heavily relies on the experiences of Mooney's own students to provide readers with examples of what students do when given in-school opportunities to explore and create works of Hip Hop-related media culture. These examples are firmly rooted in the context of a school whose student body is both extraordinarily diverse (the third-most diverse public high school in New Jersey) and extraordinarily high-performing (accepting only the highest-achieving ten percent of student applicants). As a result, they often reflect specific challenges faced by high-performing black and latinx students and their educators. Mooney explains:

Treena doesn't feel comfortable talking about race in history class, but she is drawn to spoken word poetry that confronts it. Our school is diverse, but African Americans are still in the minority and Treena's history teacher is white. Do these factors affect Treena's response to discussions of race in that classroom? Why does she become defensive and angry? (p. 81)

Mooney views Hip Hop as a vehicle for addressing these impediments to culturallyresponsive learning. His pedagogies spring from the belief that "students in urban schools should have access to museums, performances, and other aesthetic experiences that enrich their lives through the arts" (p. 9), and that, much like museums, Hip Hop offers students avenues towards cultural media literacy development. As one student identified as Eric asserts, "Hip Hop is a culture and it's just like learning about the Aztecs or Mayans" (p. 12). Yet, as Mooney is quick to note, the introduction of contemporary Hip Hop into classroom media literacy instruction can often feel much more personal and immediate to students than the study of past civilizations. For Mooney, the culture and conventions surrounding Hip Hop provide the basis for a cross-curricular philosophy of teaching critical media literacies in ways that inspire "knowledge of self" (p. 12) for both educators and students alike.

Mooney identifies four central elements of previous scholars' attempts to establish a framework for Hip Hop-based literacy instruction: DJing, breakdancing, rapping, and graffiti art. Mooney heavily draws from these pre-existing models, particularly those that are designed to bring about "the process of actively becoming aware of one's own position in the world and what to do about it" (Alim, 2007, p. 166). Mooney christens his approach Breakbeat Pedagogy, which he explains is a reference to early, pre-commercialized forms of Hip Hop literacy practice (Rose, 2008).

Mooney strives to balance descriptions of media literacy practices that examine commercial forms of Hip Hop with those that are produced outside the context of commoditization. He prompts his English language arts students to compare elements of recently-released songs by Top 40 artists with seminal works of African American authors ("She names 'society' as the force that is crushing their dreams", p. 112), while also encouraging openly-LGBT students to write self- 
reflective spoken word poetry exploring relationships between Hip Hop media and LGBT media cultures ("When Neema discusses the caterpillar transforming into the butterfly, she is asking us to look at people's identities as transformational and fluid rather than static and fixed", p. 90). Many of his pedagogies lean on the performative aspects of Hip Hop, and he refers to Sheridan Blau's (2003) work on performative critical literacy pedagogies in order to lay out a model for organizing in-school "events" (p. 40) that encourage students' full participation in their own socio-cultural reflections on Hip Hop media. Mooney includes his student Neema's rap entitled "Princess Charming" which contains these lines:

This is hard for me but my mom taught me to use my voice even when it shakes.

And I know words hold no volume

unless spoken with conviction. (Mooney, 2016, p. 88)

Mooney clearly and effectively articulates how he enacted each of his teaching practices, and often couples his descriptions with multi-page excerpts from his students' Hip Hop media works and detailed accounts of his students' literacy practices, such as his observation that one student was "pulling images from all around her immediate world, including film and literature, synthesizing these images and ideas into a powerful commentary on race, colorism, and beauty" (p. $84)$.

Scholars who are not specifically interested in efforts to bring Hip Hop media into public school literacy programs will nevertheless be drawn to this work due to the many parallels between Mooney's self-reflective pedagogical approaches and the ongoing concerns of educators involved in the incorporation of other participatory media literacy practices - such as fanfiction writing and multimedia remix culture - into school environments. For instance, central to Mooney's narrative is the rejection of contemporary academic labels such as "street art" and "street poetry" to describe Hip Hop and Rap media, which he feels "serve only to widen the chasm" (p. 9) between the media that students consume in their daily lives and the media that is traditionally presented as art to students.

This objection is by no means new to cultural scholars or media educators, and in many ways Mooney's response to Maxine Greene's clarion call to break down "the separations between 'high' and 'low' art" (Greene \& Lincoln Center Institute, 2001, p. 106) echoes twentieth-century cultural studies scholars' efforts to incorporate the everyday signs and symbols of popular culture into broader academic conceptions of aesthetically valuable media practice (Barthes, 1972; Williams, 1983).

Mooney outlines the many ways in which he feels that Hip Hop still remains outside the scope of acceptable classroom critical media literacy instruction, and much of this critique is presented through a conflict theoretical lens. For example, although Mooney cites the increasing presence of suburban white adolescents within Hip Hop fandom, to him Hip Hop "is a black art form and always will be" (p. 5). Consequently, when presenting schools that allow students to be assigned works by Kurt Vonnegut that contain crass language and depictions of explicit 
sexual situations, yet forbid Hip Hop music on the grounds of its vulgarity, Mooney concludes that this hypocrisy exists "because Vonnegut is white" (p. 110).

How a reader reacts to the preceding sentence will very much determine his overall reception of Mooney's pedagogy. At all times, Mooney asserts that his white, male, heterosexual, cis-gender and able-bodied identities have afforded "benefits and privileges that other groups of people have not been granted," and that the very nature of the US public education system is predisposed to offer his students fewer opportunities for culturally-relevant media literacy learning than were afforded to him during his own childhood (p. 7). With this constantly in his mind, Mooney makes a strong argument for a media literacy educator's "continuous reflection and self-examination" on matters of educational inequality (p. 7).

For instance, Mooney observes how "the excitement surrounding a Hip Hop event $[\ldots]$ is the essence of youth culture in a school" (p. 54), and as every high school educator knows, the essence of youth culture is far from quiet. Consequently, he contrasts the expected decorum of student participants in Hip Hop events with the expectations of silence that US public schools typically place on black adolescents. Here, Mooney draws on the anthropological connections made by Christopher Emdin (2016) between black Pentecostal churches and Hip Hop performance spaces, and practices of soliciting a crowd's verbal affirmations ("When I say, 'Hip' you say, 'Hop!", p. 43) are characterized by him as sociolinguistic breaks that ensure his students' attentiveness and engagement in literacy learning.

Mooney's accounts of his own experiences with bringing Hip Hop into school spaces are often paired with descriptions of the ways in which particular Hip Hop pedagogical practices may correspond to the stated aims of US public school literacy education, including "close-reading practices such as making inferences and predictions, identifying figurative language, analyzing theme, making connections, and synthesizing knowledge" (p. 58).

However, Mooney cautions other teachers in urban public schools against employing Hip Hop pedagogy as "a simple gimmick designed to get students interested in the literary canon" (p. 57) or "a momentary departure from traditional schooling" (p. 53). Instead, he asserts, the true value of Hip Hop pedagogy lies in its potential to transgress, rather than support, existing media literacy education practices. It offers alternatives to English language arts practices that are pedagogically and linguistically ill-suited to the intellectual development of urban public school students, and provides students with a degree of agency that "scares many administrators and teachers" (p. 53), and even "reclaims the school building" (p. 55) by granting students ownership of physical context for in-school media literacy education.

Mooney characterizes these disruptive elements of Hip Hop pedagogy as forms of "therapeutic intervention" (p. 55), ones which "shatter preconceived notions about 'articulateness' and literacy" (p. 54) in ways that both validate and affirm the media literacy practices of black and latinx youth culture. Mooney briefly touches on the notion that students from predominantly white schools might initially find these forms of participation to be uncomfortably unfamiliar. Yet, his 
subsequent lack of discussion on how a teacher's validation and encouragement might acclimate white students to cultural differences in practices of media engagement came across as a missed opportunity, and contributed to my continual feeling that Mooney's heavy focus on the disruptive qualities of Hip Hop pedagogy represented a potential blind spot within the text.

Often, I felt as though Mooney's heavy focus on the capacity of Hip Hop pedagogies to disrupt traditional school structures ignored the distinct advantages that he had been given as an educator at an elite "public school of choice" (p. 19). Although Mooney concedes that "many schools and districts likely won't allow a 'Hip Hop event"' (p.55), it feels impossible to read a paragraph that begins with the phrase "every year I teach a unit on sexism and masculinity in the media" (p. 12) and not immediately think that Mooney teaches in a different public school system than the rest of us. Mooney may assert that "it isn't enough to have students engage in dialogue about sexism in Hip Hop" (p. 57), but for many educators, this dialogue itself may represent a seemingly insurmountable hurdle in and of itself. For educators working alongside teachers and administrators who may be predisposed to inextricably link Hip Hop culture with acts of violence and disobedience, Mooney's decision to emphasize the ways in which Hip Hop pedagogy disrupts traditional school hierarchy is much more likely to hinder rather than help.

Ultimately, Mooney's pedagogical objectives are in many ways tempered with what seem to be lingering doubts: doubts about whether he has any business critiquing the misogyny, homophobia, and violence that is endemic in popular forms of commercial Hip Hop media, and whether he will always remain an outsider to the culturally-situated media literacy practices of his students. These doubts only serve to make Breakbeat Pedagogy stronger and more compelling: their inclusion within the text allows the work to convey the lived experiences of an educator who has identified that his whiteness has the potential to impede the intellectual development of his non-white students, and whose realization of this fact has driven him to maintain an unyielding focus on providing forms of media literacy instruction that are tailored to best accommodate the needs of his students. To Mooney, this means that the issues that matter to contemporary black teens, such as "race, beauty, and police brutality" (p. 116), are best approached through lenses of culturally-responsive, critical media literacy pedagogies: pedagogies that will allow for the greatest and most authentic "opportunities to think critically about the media they consume" (p. 110).

\section{REFERENCES}

Alim, H. Samy. 2007. "Critical Hip Hop Language Pedagogies: Combat, Consciousness, and the Cultural Politics of Communication." Journal of Language, Identity, and Education, 6(2):161-176.

Barthes, Roland. 1972. Mythologies (Annette Lavers, Trans.). London: Paladin. Blau, Sheridan. 2003. "Performative Literacy: The Habits of Mind of Highly Literate Readers." Voices from the Middle, 10(3):18-22. 
Emdin, Christopher. 2016. For White Folks Who Teach in the Hood... and the Rest of Ya'll Too: Reality Pedagogy and Urban Education. Boston: Beacon Press.

Greene, Maxine, and Lincoln Center Institute. 2001. Variations on a Blue Guitar: The Lincoln Center Institute Lectures on Aesthetic Education. New York: Teachers College Press.

Mooney, Brian. 2016. Breakbeat Pedagogy: Hip Hop and Spoken Word Beyond the Classroom Walls. New York: Peter Lang.

Rose, Tricia. 2008. The Hip Hop Wars: What We Talk about When We Talk about Hip Hop and Why It Matters. New York: Basic Civitas Books.

Williams, Raymond. 1983. Culture and Society, 1780-1950. New York: Columbia University Press.

Yenigun, Sami. 2015, June 13. A Visit from Kendrick Lamar - Best Day of School Ever? [Blog post].

https://www.npr.org/sections/ed/2015/06/13/413966099/a-visit-fromkendrick-lamar-best-day-of-school-ever 